\title{
Profil dan Persepsi Peminat Wisata Museum Nasional Sejarah Alam Indonesia di Kota Bogor
}

\author{
Sugiarti ${ }^{1}$, Hendra Gunawan ${ }^{2}$ \\ Affiliation \\ ${ }^{1}$ Biro Kerja Sama, Hukum dan Humas Lembaga Ilmu Pengetahuan Indonesia Kawasan \\ Bogor \\ ${ }^{2}$ Pusat Penelitian dan Pengembangan Hutan, Kementerian Lingkungan Hidup dan \\ Kehutanan \\ Correspondence \\ Sugiarti. Biro Kerja Sama, Hukum dan Humas Lembaga Ilmu Pengetahuan Indonesia \\ Kawasan Bogor, Jl.H.Juanda No.18 Bogor, 16122. Email: ugiarachim@gmail.com.
}

\begin{abstract}
The Indonesian Institute of Sciences revitalizes the Indonesian Ethnobotany Muse um into the National Museum of Indonesian Natural History (Munasain) for improving professional disemination. Munasain is relatively less visited by tourists than the Zoological Museum and the Soil and Agriculture Museum in Bogor City. This study aims to determine the profile and perceptions of those interested in Munasain to find the cause of the lack of visits and provide solutions. Questionnaires were distributed to 400 respondents. The results showed that the most interested in Munasain is the age group of 21-30 years (38.0\%). Most respondents obtained information about Munasain from social media (67.5\%). The Munasain theme of interest was $38.6 \%$ of ethnobotany, $32.3 \%$ of historical and cultural collections, $27.3 \%$ of natural history. Munasain considered special because it is a complete source of knowledge (31.2\%), the display is interesting $(29.0 \%)$, and has superior collection of ethnobotany (18.3\%). The themes of interest of the respondents were Indonesian natural and cultural history (59.3\%), eth nob otany $38.7 \%$ and other themes $2.0 \%$. For future development, $43.8 \%$ of respondents stated the need for socialization and promotion, 31.5\% expected an increase in benefits for the community, $16.0 \%$ wanted more attractive displays and $8.6 \%$ expressed the need for additional collections.
\end{abstract}

Keywords: Tourism; Museum; Ethnobotany; Visitors; Perception; Munasain.

Article Information

Submitted 18 Juli 2020 | Revised 25 September 2020 | Accepted 28 January 2021

Recommended Citation: Sugiarti., Gunawan, H. (2020). Profil dan Persepsi Peminat Wisata Museum Nasional Sejarah Alam Indonesia di Kota Bogor . Jurnal Pariwisata Terapan, 4(2), 111-130. https://doi.org/10.22146/jpt.57928 


\section{Pendahuluan}

Industri sektor pariwisata berkembang sangat cepat. Adanya otonomi daerah menjadikan masing-masing daerah berupaya menggali sebesar-besarnya potensi daerahnya yang diiringi dengan banyaknya rute-rute penerbangan, destinasi wisata baru, serta meningkatnya akomodasi yang sangat berpotensi meningkatkan perekonomian (Abdillah et al., 2016). Indonesia adalah salah satu negara yang mempunyai beragam objek wisata dikarenakan keadaan alam, flora, dan fauna, sebagai karunia Tuhan yang Maha esa, serta peninggalan purbakala, peninggalan sejarah, seni, dan budaya yang dimiliki (Kirom et al., 2016). Museum merupakan salah satu Obyek Destinasi Tujuan Wisata (ODTW) yang dimiliki oleh hampir setiap daerah di Indonesia, namun semakin tersisih dalam persaingan pasar jasa wisata. Hal ini menurut Suryasih (2010) karena museum sering dipersepsikan hanya sebagai tempat menyimpan benda-benda kuno, antik, dan barang-barang yang tidak berguna lagi di era modern ini, sehingga kurang diminati untuk dikunjungi.

Menurut Code of Ethics for Museums yang dikeluarkan oleh International Council of Museum (ICOM), museum adalah lembaga nirlaba dan permanen untuk melayani masyarakat, dan terbuka untuk umum, dengan tugas mengumpulkan, merawat, meneliti, mengkomunikasikan dan memamerkan benda-benda/bukti tentang manusia dan lingkungannya untuk kepentingan penelitian, pendidikan, dan rekreasi (ICOM, 2017). Museum bisa menjadi salah satu sarana komunikasi pembangunan kualitas sumber daya manusia dalam konteks mengembangkan semangat belajar dari segenap masyarakat, agar senantiasa memahami keadaanya, masalah-masalah yang dihadapi, dan upaya-upaya pemecahan masalah, agar dapat terus-menerus memperbaiki kualitas hidup (Mardikanto, 2010).

Museum sebagai tempat menyimpan benda-benda peninggalan sejarah, seni, budaya, benda kuno dan ilmu pengetahuan masa lalu (https://kbbi.web.id/museum) mengandung nilai-nilai kearifan yang dapat digunakan untuk melatih kecerdasan, membentuk sikap, watak dan kepribadian peserta didik (Karyono, 2010). Mempelajari sejarah masa lalu melalui museum memiliki arti strategis dalam pembentukan watak dan peradaban bangsa yang bermartabat serta dalam pembentukan manusia Indonesia yang memiliki rasa kebangsaan dan cinta tanah air (Karyono, 2010). Keberadaan museum dalam dunia pendidikan begitu dibutuhkan, termasuk dalam pembelajaran sejarah. Seorang siswa sekolah dasar lebih senang bila belajar di museum, dibandingkan dengan di dalam kelas (Asmara, 2019).

Kota Bogor dan Kabupaten Bogor memiliki memiliki sembilan museum, yaitu Museum Zoologi, Museum PETA (Pembela Tanah Air), Museum Perjuangan, Museum Tanah dan Pertanian, Museum Nasional Sejarah Alam Indonesia (sebelumnya adalah Museum Etnobotani Bogoriense), dan Museum Balai Kirti yang semuanya terletak di sekitar Kebun Raya Bogor, sementara Museum Herbarium Bogoriense, Museum Mobil dan Keramik, serta Museum Pasir Angin berlokasi di wilayah Kebupaten Bogor (http://www.disparbud. jabarprov.go.id/). Museum Nasional Sejarah Alam Indonesia atau disingkat Munasain merupakan hasil revitalisasi dan pengembangan dari Museum Etnobotani Indonesia (MEI). Museum Etnobotani Indonesia adalah museum yang menyimpan berbagai tanaman dari Indonesia yang berkaitan dengan budaya atau etnis masyarakat setempat (http://www.lipi.go.id/). Museum Etnobotani Indonesia didirikan pada tahun 1982 dan 
diresmikan oleh Menteri Riset dan Teknologi kala itu, B. J. Habibie. Sedangkan Munasain diresmikan oleh Wakil Kepala LIPI, Dr. Akmadi Abbas, yang didampingi Walikota Bogor, Dr. Bima Arya pada 31 Agustus 2016 (http://munasain.lipi.go.id/).

Meskipun memiliki peran dan fungsi penting dalam pembangunan karakter bangsa, museum masih jarang dikunjungi, baik sebagai wahana rekreasi maupun untuk menimba pengetahuan. Sebagai contoh, jumlah pengunjung lima museum di Kota Bogor hanya $20 \%$ dari total wisatawan yang berwisata di Kota Bogor pada tahun 2016 sebanyak 5.262.224 orang. Bahkan wisatawan yang berkunjunh ke Munasain hanya Munasain hanya 0,12\% (BPS Kota Bogor 2018; 2020). Bahkan empat museum di sekitar Candi Borobudur, menurut Wahyuningsih, 2020 hanya dikunjungi oleh 1-2,5\% dari total pengunjung Taman Wisata Candi Borobudur. Hal tersebut menurutnya disebabkan oleh kurangnya promosi, karena sekitar 0-29\% yang mengetahui ada empat museum tersebut. Faktor lain adalah pengelola belum memberikan pengalaman kunjungan yang optimal kepada pengunjung melalui museum-museum tersebut dan belum menempatkan muesum sebagai obyek yang menarik. Upaya revitalisasi MEI menjadi Munasain merupakan upaya korektif agar museum dapat berfungsi secara optimal sebagai sarana untuk mengkomunikasikan informasi dengan lebih baik dan profesional. Munasain hasil revitalisasi memiliki lima lantai yang memiliki satu rangkaian cerita yang saling berkesinambungan. Lantai pertama berisi pengenalan tentang awal mula perkembangan penelitian hayati di Indonesia. Lantai kedua berisikan keanekaragaman tipe ekosistem di Indonesia dan keterkaitannya dengan manusia. Dua lantai sisanya memberikan informasi mengenai kearifan lokal masyarakat Indonesia dan pengetahun dari masa ke masa terhadap pemanfaatan keanekaragaman hayati (http://munasain.lipi.go.id/).

Munasain dirancang untuk bisa mengakomodir generasi muda, antara lain melalui multimedia agar lebih menarik, edukatif, komunikatif, dan interaktif. Sebagai salah satu lembaga di bawah Lembaga Ilmu Pengetahuan Indonesia (LIPI), Munasain merupakan museum berbasis sains dengan tujuan memberikan pendidikan yang berkesinambungan bagi pengunjung, mengenalkan sejarah alam Indonesia, budaya, dan keanekaragaman hayati yang menjadi identitas bangsa. Munasain sangat penting, mengingat Indonesia merupakan negara dengan kekayaan sumber daya hayati nomor satu di dunia dan generasi muda perlu menyadarinya dengan mempelajarinya di Munasain sehingga tergugah ikut berpartisipasi melestarikan, memelihara, dan menjaga alam Indonesia ( http://lipi.go.id/).

Untuk meningkatkan jumlah kunjungan ke Munasain, perlu dilakukan upaya dari dua sisi. Di satu perlu dilakukan pembenahan terhadap museum seperti penambahan koleksi, desain display, produk layanan dan koleksi tematik yang berbeda dari museum lainnya. Dengan demikian dapat memberikan pengalaman yang optimal kepada pengunjung. Di sisi lain perlu dilakukan penelitian untuk mengetahui profil pengunjung dan minat mereka terhadap museum serta hal-hal yang mereka ingin lihat dan ketahui di Munasain. Hal ini sejalan dengan pendapat Akbar (2010) yang mengatakan bahwa telah terjadi pergeseran paradigma pengelolaan museum dari yang berorientasi pada benda-benda koleksi, kini menjadi berorientasi kepada pengunjung. Oleh karena itu penelitian pengunjung aktual dan potensial sangat penting untuk mengetahui kebutuhan mereka terhadap museum (Falk, 2012). 
Penelitian ini bertujuan untuk mengetahui profil dan persepsi peminat (pengunjung dan calon pengunjung) Munasain. Hasil penelitian ini sangat bermanfaat sebagai bahan masukan dalam pengembangan dan pengelolaan Munasain di masa yang akan datang, terutama dalam hal melakukan sosialisasi dan promosi, serta dalam hal merencanakan pengumpulan koleksi dan merancang desain, tata letak display serta metode edukasi pengunjung.

\section{Metode}

Penelitian ini dilaksanakan pada bulan April-Mei tahun 2020 bertempat di Bogor, Jawa Barat. Metode penelitian ini termasuk metode deskriptif yaitu suatu metode dalam meneliti status sekelompok manusia, suatu obyek, suatu set kondisi, suatu sistem pemikiran ataupun suatu kelas peristiwa pada masa sekarang dengan ujuan untuk membuat deskripsi secara sistematis, faktual dan akurat mengenai fakta-fakta, sifat-sifat serta hubungan antar fenomena yang diteliti (Nazir, 1988).

Pengumpulan data primer menggunakan instrumen berupa kuesioner berisi pertanyaan dengan jawaban kategorikal (tertutup) dan jawaban tidak berstruktur (terbuka) berupa isian (Sarwono, 2006). Kuesioner dibagikan kepada 400 pendaftar webinar "Ngabuburit di Munasain". Menurut Kamus Bahasa Sunda yang diterbitkan oleh Lembaga Bahasa dan Sastra Sunda (LBSS), kata 'ngabuburit' berarti ngalantung ngadagoan burit, yang artinya bersantai-santai sambil menunggu waktu sore (antara jam 15.30-17.30) atau usai shalat Ashar, sebelum matahari terbenam atau waktu berbuka puasa (http://www.jurnas.com). Acara ngabuburit di Munasain dilaksanakan pada tanggal 18 Mei 2020 pukul 16.00-17.30 dengan tema "Covid-19: Munasain, Traditional Knowledge, and Science", Data sekunder berupa data wisatawan yang berkunjung ke ODTW di Kota Bogor diunduh dari situs resmi Badan Pusat Statistik Kota Bogor (http://bogorkota.bps.go.id/) dan situs resmi Munasain (http://munasin.lipi.go.id/).

Analisis data dilakukan menggunakan Microsoft Excel untuk mengukur tendensi (Sarwono, 2006) dan uji Chi square untuk menguji kebebasan dalam tabel kontingensi (Gaspersz, 1991; Sugiyono 1999). Uji Chi square tersebut untuk mengetahui ada atau tidaknya hubungan antar variabel bebas dan variabel tergantung (Sarwono, 2006). Langkah berikutnya adalah mendeskripsikan hasil penelitian dalam bentuk narasi, gambar atau tabel kemudian dibahas dengan melibatkan rational knowledge peneliti untuk mendapatkan kesimpulan (Satori dan Komariah, 2009).

\section{Hasil dan Pembahasan \\ Dinamika Pariwisata Kota Bogor}

Kota Bogor memiliki banyak obyek daerah tujuan wisata (ODTW) baik yang alami maupun buatan. Beberapa obyek wisata yang populer antara lain Kebun Raya Bogor, Istana Bogor, Museum Zoologi, Museum PETA, Museum Perjuangan, Museum Tanah dan Pertanian, Museum Nasional Sejarah Alam Indonesia (Munasain), Situ Gede, Prasasti Batutulis dan The Jungle. Jumlah pengunjung wisata ke Kota Bogor dari tahun 2008-2016 mengalami pertumbuhan sebesar 9,2\% per tahun. Pada tahun 2016 jumlah wisatawan yang berkunjung ke Kota Bogor mencapai 5.262.224 orang, dengan jumlah terbesar berkunjung ke Kebun Raya Bogor yang mencapai 1.432 .666 orang atau $27,2 \%$. Sementara itu, lima museum dan Istana Presiden yang ada di Kota Bogor dikunjungi oleh 1.095.379 wisatawan (20,8\%). 
Selebihnya sebanyak 52,0\% wisatawan tersebar ke berbagai ODTW di Kota Bogor (BPS Kota Bogor 2018; 2020).

Meskipun persentase pengunjungnya baru $20,8 \%$, lima museum ditambah dengan istana kepresidenan dapat menjadi andalan Kota Bogor dalam menjaring wisatawan. Hal ini karena ODTW tersebut lokasinya berdekatan di sekitar Kebun Raya Bogor sehingga dapat menjadi satu paket wisata yang menarik namun murah. Untuk kategori museum, Museum Zoologi masih paling banyak dikunjungi wisatawan yaitu mencapai $83,5 \%$ dari seluruh pengunjung museum di tahun 2016. Sementara Munasain berada di urutan ke empat dengan 1,4\% dari total pengunjung museum. Jika dibandingkan terhadap total pengunjung ke semua ODTW di Kota Bogor, yang berkunjung ke Munasain hanya $0,12 \%$.

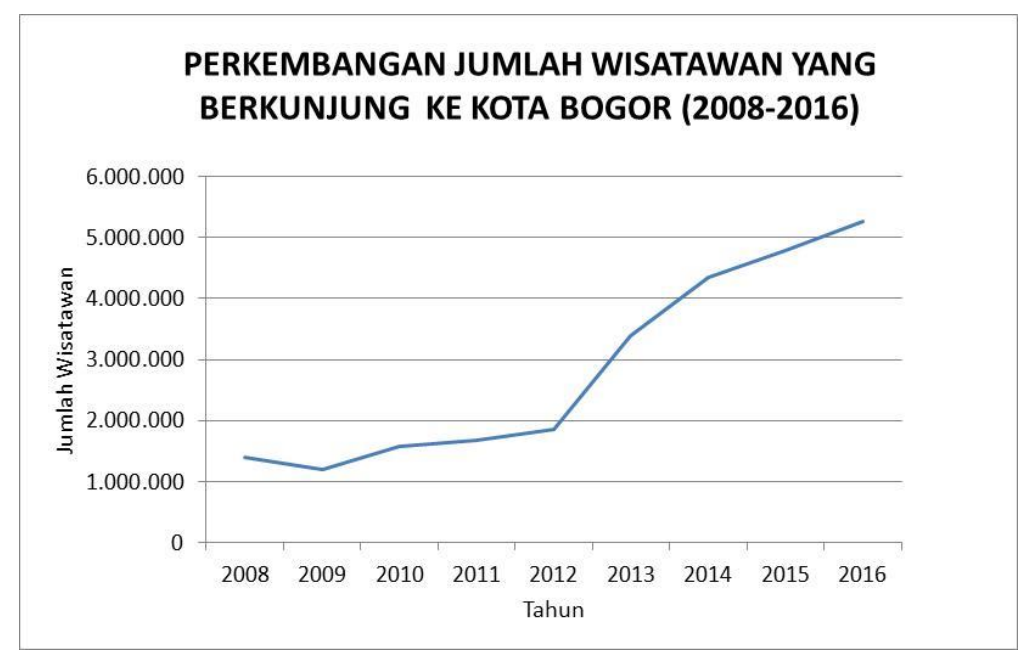

Gambar 1. Perkembangan jumlah wisatawan yang berkunjung ke Kota Bogor tahun 2008-2016 (Diolah dari sumber: BPS Kota Bogor 2020)

Museum Zoologi banyak dikunjungi wisatawan karena merupakan satu paket wisata dengan Kebun Raya Bogor dan lokasinya berada di dalam areal Kebun Raya Bogor. Munasain, yang masih dalam pengelolaan di bawah Lembaga Ilmu Pengetahuan Indonesia (LIPI) semestinya bisa dijadikan satu paket dengan Kebun Raya Bogor dan Museum Zoologi. Hal ini karena masih di bawah satu pengelola (LIPI) dan substansinya juga sangat erat kaitannya dengan ODTW yang ditawarkan di Museum Zoologi dan Kebun Raya Bogor. Oleh karena itu, ke depan perlu peningkatan dalam hal promosi dan sosialisasi kepada publik, terutama generasi muda pelajar dan mahasiswa. Disamping itu, juga perlu peningkatan jumlah substansi materi dan koleksi museum sebagai daya tarik wisata serta peningkatan fasilitas dan pelayanannya. 


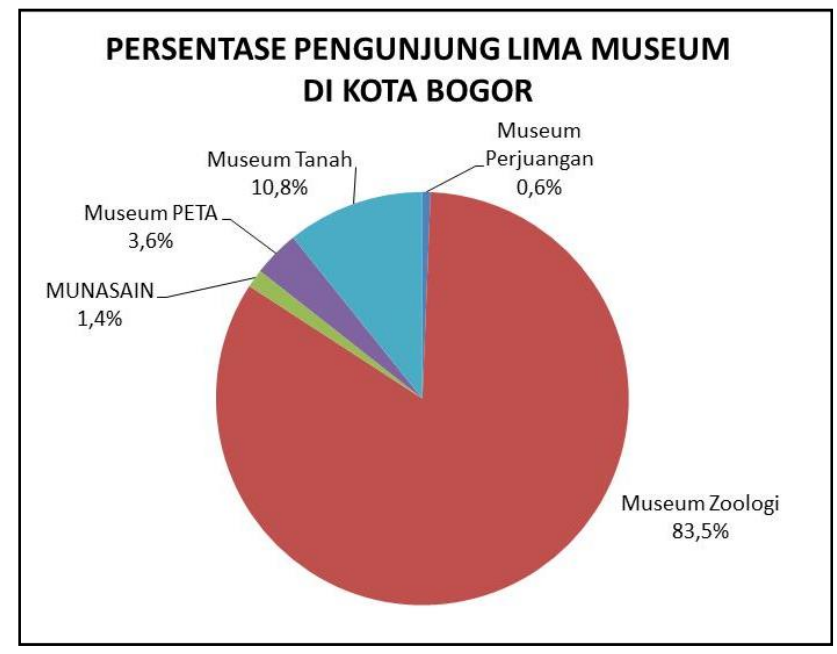

Gambar 2. Persentase pengunjung lima museum di Kota Bogor, 2016.

\section{Profil Peminat Munasain}

Mengetahui calon pengunjung Munasain, merupakan langkah awal yang penting dalam menyusun strategi sosialisasi dan promosi ke depan. Dengan mengetahui profil para peminat atau calon pengunjung Munasain maka dapat ditetapkan target, dibuat substansi informasi, metode mengkomunikasikannya dan media yang digunakan. Menurut Purbohastuti (2017) informasi yang sesuai dengan latar belakang budaya masyarakat akan diterima, sedangkan yang tidak sesuai akan cenderung diabaikan atau bahkan ditolak.

\section{Gender dan Umur}

Ada 399 peserta yang mendaftar acara "Ngabuburit di Munasain" yang terdiri atas laki-laki $42 \%$ dan perempuan $58 \%$. Hasil tersebut hampir mirip dengan hasil penelitian Gaffar (2011) yang juga menemukan pengunjung museum di Kota Bandung $56 \%$ pengunjung wanita (56\%) dan pengunjung laki-laki (44\%). Angka tersebut menunjukkan minat yang lebih kuat pada kelompok perempuan, apalagi jika mengingat pada jam 16.00-17.30 di bulan Ramadhan, umumnya kaum perempuan sedang sibuk menyiapkan makanan untuk berbuka puasa.

Fakta lain menunjukkan bahwa peminat Munasain terbesar adalah kelompok umur 21-30 tahun. Kelompok umur ini merupakan kelompok umur produktif yang umumnya terdiri atas mahasiswa dan pekerja muda. Urutan kedua terbanyak yang berminat pada Munasain adalah kelompok umur 31-40 tahun yang umumnya merupakan usia kerja dengan masa kerja lebih dari lima tahun sampai 15 tahun atau dapat dikatakan sebagai kelompok yang sudah mapan perekonomiannya. Kelompok pelajar dengan kelas umur sampai dengan 20 tahun berada di posisi keempat dengan 11,1\%. Padahal kelompok umur pelajar merupakan kelompok yang potensial sebagai pengunjung museum, mengingat berkunjung ke museum merupakan salah satu kompenen penting dalam proses pembelajaran sebagai sumber belajar (Yusuf et al., 2018). Menurut Handoko et al., (2018) pemanfaatan museum sebagai media pembelajaran mempunyai peranan yang penting bagi peserta didik, walaupun pesepsiyang didapat oleh peserta didik berbeda-beda. 


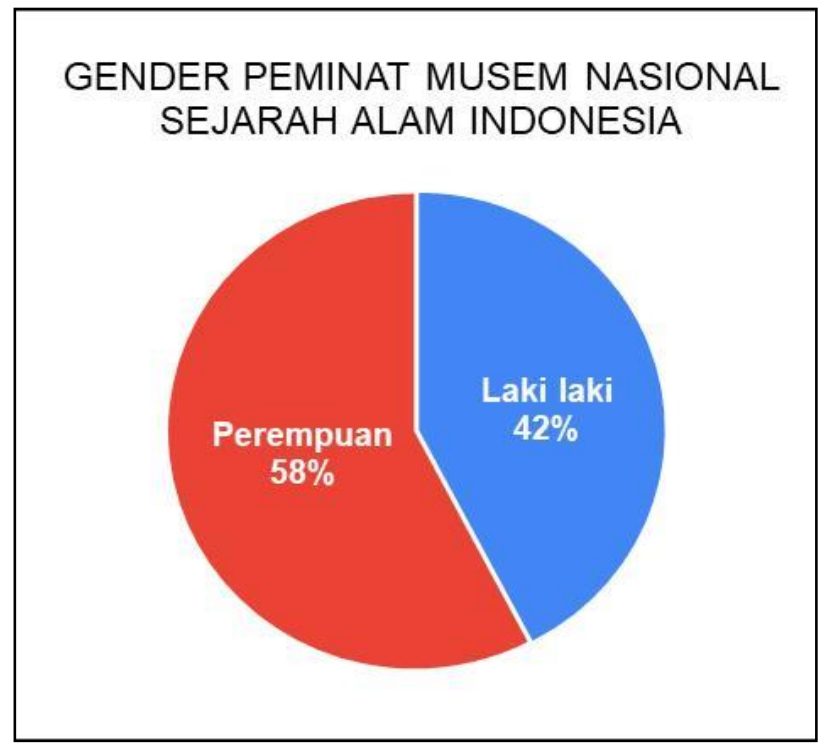

Gambar 3. Gender peminat museum nasional sejarah alam Indonesia, 2020

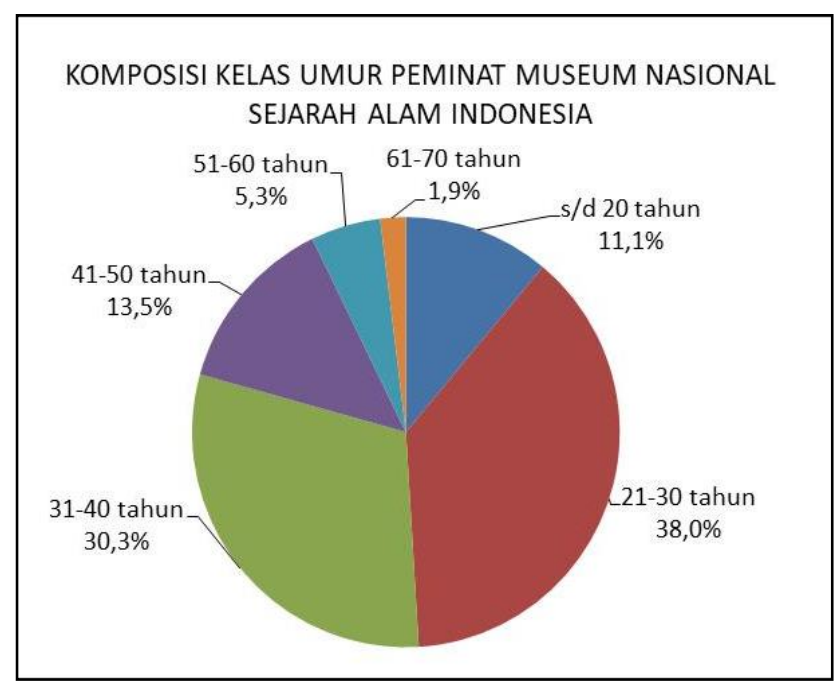

Gambar 4. Kom posisi kelas umur peminat muse um nasional sejarah alam Indonesia, 2020.

\section{Latar Belakang Organisasi}

Peserta acara Ngabuburit di Munasain berasal dari berbagai lembaga atau organisasi, baik pemerintah maupun non pemerintah. Latar belakang organisasi peserta dikelompokkan ke dalam tujuh kategori yaitu: Perguruan Tinggi negeri maupun swasta, Lembaga Riset kementerian maupun non kementerian, Sekolah Menengah (SMA dan SMP), Lembaga Pemerintah baik pusat maupun daerah (selain lembaga riset), Masyarakat Umum yang tidak menginduk kepada organisasi manapun, Lembaga Swasta termasuk perusahaan swasta dan rumah sakit swasta, serta Komunitas.

Para akademisi dari Perguruan Tinggi paling banyak mengikuti acara Ngabuburit di Munasain yaitu mencapai $52,4 \%$, kemudian lembaga riset $18,0 \%$ dan masyarakat umum 13,5\%. Hal ini diduga disebabkan acara Ngabuburit diisi dengan pemaparan hasil riset 
yang terkait dengan covid-19. Disamping topiknya aktual, nuansa riset menjadi daya tarik para akademisi dan peneliti.

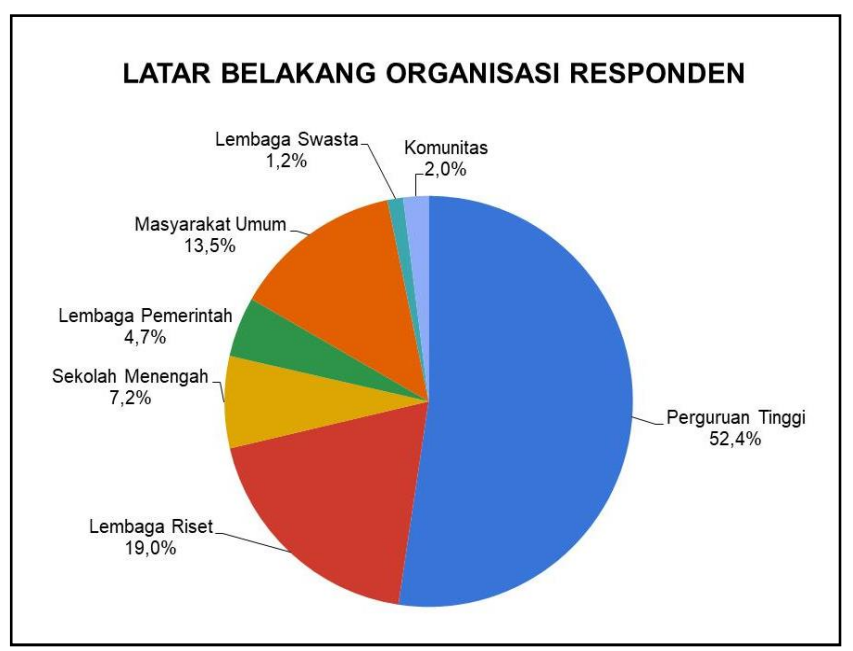

Gambar 5. Latar belakang organisasi responden peserta "Ngabuburit di Munasain",2020.

\section{Profesi}

Berdasarkan profesinya atau status pekerjaannya para responden peminat Munasain dapat dikelompokkan menjadi: dosen, peneliti, mahasiswa, guru, pelajar, penyuluh, Pegawai Negeri Sipil (PNS) dan masyarakat umum. Kategori peneliti terdiri atas pranata labortorium, perekayasa dan peneliti. Kategori pelajar terdiri atas siswa Sekolah Menengah Pertama (SMP) atau sederajat dan siswa Sekolah Menengah Atas (SMA) atau sederajat. Sementara masyarakat umum terdiri atas orang yang belum bekerja, pekerja swasta, wiraswasta dan responden yang tidak spesifik menyebut pekerjaannya hanya menyatakan "umum" dalam kolom pekerjaan. Dosen dan mahasiswa merupakan peminat utama terhadap Munasain, diikuti oleh peneliti dan PNS. Menurut Nuraeni (2014), variabel yang berpengaruh terhadap minat kunjung ulang promosi, kualitas pelayanan dan variabel daya tarik wisata. Tampaknya kurangnya kunjungan ke Munasain oleh kelompok tertentu seperti pelajar dan masyarakat umum disebabkan Munasain kurang terpromosikan terhadap kelompok tersebut. Sementara dosen, mahasiswa dan peneliti lebih banyak mengetahui keberadaan Munasain dan memiliki kepentingan terkait dengan profesinya. 


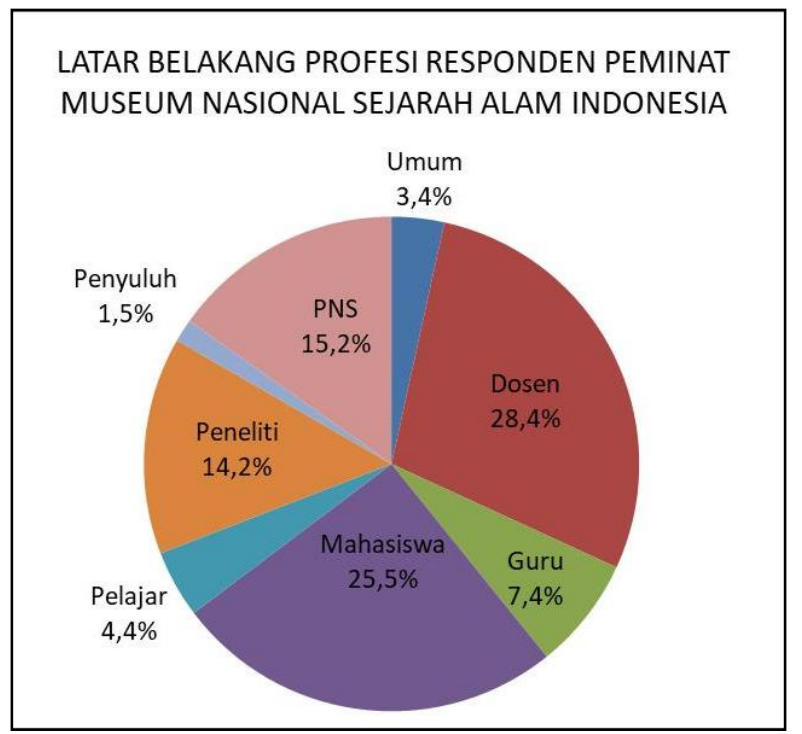

Gambar 6. Latar belakang profesi peminat Museum nasional sejarah alam Indonesia, 2020.

\section{Asal daerah}

Dari 400 peserta yang mendaftar untuk mengikuti acara Ngabuburit di Munsain terdapat 323 peserta yang mengisi alamat asal dan setelah direkapitulasi terdapat 28 povinsi asal peserta dan dua peserta luar negeri masing-masing dari Malaysia dan Cambridge, Inggris. Peserta terbanyak berasal dari Provinsi Jawa Barat (22,9\%), DKI Jakarta (22,6\%), Jawa Timur $(12,1 \%)$, Sulawesi Selatan (8,4\%), dan Jawa Tengah (6,8\%). Tabel.1 dalam lampiran.

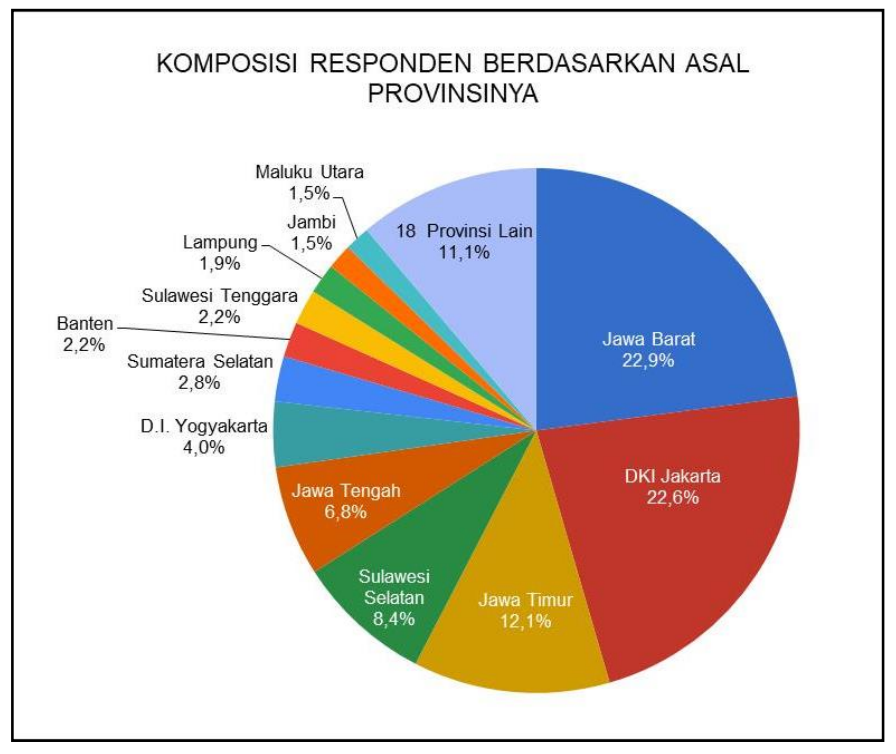

Gambar 7. Komposisi peserta berdasarkan asalnya, 2020.

\section{Persepsi dan Aspirasi Peminat Munasain}

Menurut Kamus Besar Bahasa Indonesi (KBBI on line) persepsi adalah tanggapan (penerimaan) langsung dari sesuatu atau proses seseorang mengetahui beberapa hal melalui panca indranya. Persepsi berasal dari bahasa Latin (perceptio, percipio) yang berarti tindakan menyusun, mengenali, dan menafsirkan informasi sensoris guna memberikan 
gambaran dan pemahaman tentang lingkungan (Schacter et al. 2011). Aspirasi menurut $\mathrm{KBBI}$ on line adalah harapan dan tujuan untuk keberhasilan pada masa yang akan datang. Mengetahui persepsi dan aspirasi masyarakat terhadap Munasain dapat menjadi bahan pertimbangan dalam meningkatkan pelayanan dan perbaikan pengelolaan di masa mendatang.

\section{Pengetahuan tentang Munasain}

Untuk dapat mempersepsikan suatu obyek atau informasi maka perlu mengenal atau mendapatkan informasi tersebut. Sebagian besar responden memperoleh informasi tentang Munasain dari media sosial (67,5\%) seperti facebook, Instagram, Whatsapp, Twitter dan Youtube. Sekitar seperempat responden mengetahuinya dari teman $(25,4 \%)$ dan sebagian kecil mengetahui Munasain dari media cetak, brosur dan televisi (7,0\%). Dari data tersebut terbukti bahwa media sosial sangat efektif sebagai media untuk mensosialisasikan atau mempromosikan Munasin. Jika melihat kelompok umur peminat munasain terbesar adalah kelompok umur 21-30 tahun. Kelompok ini didominasi oleh mahasiswa dan pekerja muda yang biasanya aktif menggunakan media sosial.

Menurut (Purbohastuti, 2017) mahasiswa lebih tertarik promosi melalui media sosial terutama Instagram, dibandingkan televisi dan media cetak, karena media sosial mudah diakses dimana saja dan kapan saja, dan selalu update, serta lebih luas jangkauannya. Sarana media sosial seperti facebook, twitter, dan sebagainya memang efektif untuk berinteraksi serta menjalin komunikasi dengan publik yang lebih luas (Suryani, 2014). Promosi melalui media sosial menjadi strategi pemasaran yang cukup efektif (Pamungkas \& Zuhroh, 2016), apalagi jika didukung dengan promosi dari mulut ke mulut (word of mouth communication) dengan pemberitaan positif dan berisi rekomendasi (Kotler \& Keller, 2007), maka akan menarik banyak pengunjung.

\section{Frekuensi Kunjungan}

Dari 220 responden yang mengisi kuesioner, 73,2\% belum pernah berkunjung ke Munasain dengan alasan rumahnya jauh, belum punya kesempatan atau tidak mengetahui keberadaan dan daya tarik Munasain. Sebanyak 14,5\% responden pernah berkunjung sekali, 5,9\% pernah berkunjung antara 2-5 kali dan 6,4\% pernah berkunjung ke Munasain lebih dari 5 kali. Pengunjung yang datang lebih dari satu kali umumnya memiliki kepentingan seperti dalam rangka penelitian, mencari referensi atau karena pekerjaannya terkait dengan Munasain. Sebanyak 73,2\% yang belum pernah berkunjung merupakan peminat terhadap Munasain yang potensial menjadi pengunjung di masa mendatang. Selain potensial menjadi pengunjung, mereka juga potensial menjadi "agen" untuk mempromosikan Munasain kepada orang lain melalui cara dari mulut ke mulut (word of mouth communication), atau mengajak orang lain berkunjung ke Munasain. Oleh karena itu, menjadi penting untuk memberikan informasi yang baik dan lengkap kepada mereka melalui kegiatan Webinar Ngabuburit di Munasain yang mereka ikuti. Disamping itu juga penting untuk mengetahui secara lebih detail tentang substansi atau koleksi yang mereka minati. 


\section{Objek yang Diinginkan Ada di Munasain}

Museum nasional sejarah alam Indonesia (Munasain) merupakan satu-satunya museum sejarah alam di Indonesia. Munasain merupakan pengembangan atau revitalisasi Museum Etnobotani Indonesia (MEI). Meskipun dari namanya bisa dipersepsikan apa isinya, namun kepada peserta webinar ditanyakan tentang substansi apa yang mereka ingin lihat atau mereka minati di Munasain? Dari 220 peserta yang menjawab, sebanyak 38,6\% ingin melihat dan memperoleh pengetahuan tentang etnobotani, 32,3\% berminat pada pengetahuan dan koleksi sejarah dan budaya, $27,3 \%$ ingin mengenal sejarah alam Indonesia dan $1,8 \%$ tertarik ada obyek lain.

\section{Persepsi terhadap Munasain}

Peserta yang pernah berkunjung ke Munasain atau mengetahui Munasain melalui virtual tour maupun media lainnya ditanyakan persepsi mereka tentang hal yang membuat Munasain memiliki keistimewaan atau keunikan dibandingkan dengan museum lain yang pernah mereka ketahui atau kunjungi. Jawaban mereka dikelompokkan menjadi enam kategori yang disajikan pada Tabel 2 pada lampiran. Sebanyak 31,2\% mengatakan Munasain merupakan sumber pengetahuan etnobotani dan sejarah alam Indonesia yang lengkap. Display baru yang merupakan hasil revitalisasi juga menjadi perhatian besar dari para responden. Sebanyak $29,0 \%$ mengatakan tata letak dan desain display Munasain menarik, sedangkan 18,3\% mengatakan koleksi etnobotani sebagai ungggulan Munasain.

\section{Minat Terhadap Tema Munasain}

Secara umum, responden memiliki minat terhadap tema Sejarah alam dan budaya Indonesia (59,3\%), tema etnobotani $38,7 \%$ dan sisanya 2,0\% menginginkan adanya tema lain namun tidak menyebut spesifik tema yang dimaksud. Minat dari masing-masing kelompok profesi terhadap tema tertentu di Munasain disajikan pada Tabel 3 dalam lampiran. Dari Tabel 3 tersebut tampak peta yang menggambarkan profesi tertentu dengan tema yang diminati. Untuk mengetahui apakah ada hubungan antara profesi responden dengan minat terhadap tema tertentu dari Munasain, maka dilakukan uji Khi kuadrat $\left(\chi^{2}\right)$. Dari Tabel 3 dapat dilakukan uji Khi kuadrat untuk mengetahui apakah ada hubungan antara profesi responden dengan tema yang diminati dari Munasain dengan hipotesis:

Ho : Tidak ada hubungan antara profesi responden dengan minat terhadap tema tertentu.

H1 : Ada hubungan antara profesi responeden dengan minat terhadap tema tertentu.

Hasil penghitungan $\chi^{2}$ hitung diperoleh nilai 10,7 yang lebih kecil daripada nilai $\chi^{2}(0.05 ; 14)$ yaitu 23,7. Dengan demikian Ho diterima yang berarti tidak ada hubungan antara profesi responden dengan minat terhadap tema tertentu.

\section{Aspirasi untuk Munasain ke Depan}

Ada 162 responden yang mengisi kolom aspirasi dalam kuesioner. Untuk pengolahan data aspirasi, responden dikategorikan menjadi delapan yaitu : umum, dosen, guru, mahasiswa, pelajar, peneliti, penyuluh, dan pegawai negeri sipil (PNS). Aspirasi atau harapan responden yang terkumpul dikelompokkan menjadi empat yaitu: yang terkait dengan display, terkait dengan penambahan koleksi, terkait dengan manfaat, fungsi dan peran Munasain, serta 
yang terkait dengan perlunya upaya mensosialisasikan dan mempromosikan Munasain kepada khalayak luas. Hubungan antara profesi responden dan aspirasi terhadap Munasain dipetakan dalam Tabel 4 pada lampiran.

Secara umum tampak bahwa 43,8\% responden menyarankan perlunya Munasain melakukan sosialisasi dan promosi agar Munasain lebih dikenal oleh masyarakat luas, khususnya generasi muda. Sebanyak 31,5\% responden mengharapkan Munasain lebih banyak lagi memberikan manfaat khususnya dalam meningkatkan pengetahuan dan kepedulian masyarakat terhadap kelestarian kekayaan sumber daya alam Indonesia. Sebanyak 16,0\% responden masih menginginkan agar tampilan tata letak dan desain pameran koleksi (display) tetap diperhatikan dan terus dikembangkan agar lebih menarik generasi muda. Sebanyak $8,6 \%$ reponden sangat perhatian dengan perlunya penambahan koleksi, baik etnobotani maupun sejarah alam dan kebudayaan Indonesia.

Untuk mengetahui lebih jauh hubungan antara profesi responden dan aspirasi terhadap Munasain maka dilakuka uji Khi kuadrat dengan hipotesis sebagai berikut:

Ho: Tidak ada hubungan antara profesi responden dengan aspirasi terhadap Munasain

H1: Ada hubungan antara profesi responden dengan aspirasai terhadap Munasain

Hasil penghitungan diperoleh nilai $\chi^{2}$ hitung sebesar 30,6 atau lebih kecil dariada $\chi^{2}(0.05 ; 21)$ yaitu 32,7 . Dengan demikian menerima Ho yang berarti tidak ada hubungan antara profesi responden dengan aspirasi terhadap Munasain. Memang dari Tabel 4 tampak bahwa aspirasi paling banyak adalah usulan untuk melakkan sosialisasi dan promosi, namun hal ini diusulkan oleh hampir semua profesi. Demikian juga dengan peningkatan manfaat Munasain diusulkan oleh semua profesi, meskipun dengan proporsi yang beragam.

\section{Implikasi Manajemen di Masa Mendatang}

Dari temuan data dan fakta yang telah diuraikan membawa implikasi pada upaya pengelolaan Munasain di masa mendatang. Temuan fakta bahwa Munasain masih belum banyak dikenal oleh masyarakat dan data bahwa jumlah pengunjung ke Munasain yang masih berada di urutan ke empat dari lima museum yang ada di Kota Bogor, berimplikasi pada perlunya upaya sosialisasi dan promosi yang terus ditingkatkan. Mengacu kepada Kamus Besar Bahasa Indonesia (KBBI on line) sosialisasi adalah upaya memasyarakatkan sesuatu sehingga menjadi dikenal, dipahami, dihayati oleh masyarakat, sedangkan promosi dapat diartikan sebagai kegiatan komunikasi untuk meningkatkan jumlah pengunjung Munasain melalui pameran, periklanan, demonstrasi, dan usaha lain yang bersifat persuasif. Promosi bertujuan menginformasikan (informing), mempengaruhi dan membujuk (persuading) serta mengingatkan (reminding) pelangggan (Tjiptono, 2001).

Sosialisasi dan promosi merupakan fungsi public relations. Hal ini sejalan dengan yang dinyatakan oleh Ruslan (2012) bahwa fungsi public relation antara lain adalah menyebarkan informasi, meningkatkan citra dan mempromosikan. Menurut Nova (2009) fungsi public relations atau humas adalah menumbuhkan dan mengembangkan hubungan baik antar lembaga dengan publiknya, internal maupun eksternal dalam rangka menanamkan pengertian, menumbuhkan motivasi dan partisipasi publik dalam upaya menciptakan iklim 
pendapat (opini publik) yang menguntungkan lembaga. Humas adalah fungsi manajemen yang menilai sikap publik, mengidentifikasi kebijaksanaan dan tata cara seorang atau organisasi demi kepentingan publik, serta merencanakan dan melakukan suatu program kegiatan untuk meraih pengertian dan dukungan publik (Cutlip et al. 2009).

LIPI sebagai lembaga yang menaungi Munasain memiliki 19 orang Pranata Humas yang ditempatkan di kawasan Bogor dengan area kerja Kebun Raya Bogor, Museum Zoologi dan Munasain. Dalam pengelolaan Munasain, Pranata Humas LIPI dapat mengambil peran sesuai dengan fungsi humas sebagaimana dinyatakan oleh Cutlip et al. (2009) yaitu: publicity, advertising, press agency, public affairs, issue management, lobbying, investor relations, dan devlopment.

Dalam hal publisitas, humas dapat menjadi sumber berita untuk konsumsi media dengan membuat press release. Humas juga dapat mengiklankan pesan-pesan yang ingin disampaikan kepada publik dengan basis sponsorship (advertising). Humas adalah press agency sehingga dapat membuat acara yang bernilai berita sehingga diliput oleh media masa. Sebagai public affair, Pranata Humas membangun dan memelihara hubungan baik antara lembaga pemerintah dan masyarakat untuk mempengaruhi kebijakan publik. Manajemen isu dilakukan oleh Pranata Humas untuk mengantisipasi dan mitigasi risiko yang merugikan dari isu yang berkembang, antara lain dengan membuka komunikasi melalui forum diskusi dan surat pembaca. Lobi-lobi mungkin perlu dilakukan oleh Pranata Humas ketika ada penerapan kebijakan atau pembuatan peraturan yang akan berdampak pada pengelolaan Munasain. Pranata Humas dapat menciptakan dan memelihara hubungan saling menguntungkan dengan stakeholders dalam konteks keuangan sebagai suatu investasi. Sebagai Pranata humas lembaga non profit perlu menciptakan dan memelihara hubungan dengan para donor dan sukarelawan utuk menjamin keberlangsungan operasional Munasain.

Dalam menjalankan fungsinya Pranata Humas LIPI menggunakan media sosial antara lain Youtube, Facebook (http://facebook.com/munasainbogor/), Instagram (https://www.instagram.com/explore/tags/munasain/), Twitter (https://twitter.com/ munasain) dan website resmi Pusat Penelitian Biologi LIPI (http://www.biologi. lipi.go.id/). Disamping itu, Munasain juga memiliki agenda rutin seperti: night at the museum, ngabuburit di Munasain, open house museum, sekolah tari tradisional, talkshow, menggambar bersama, pameraan temporer, workshop konservasi koleksi museum, nonton bareng, pameran manusia dan lingkungan, tour de museum dan pentas tari. Dalam penyelenggaraan berbagai event, peranan humas sangat penting, mulai dari menulis rilis untuk media, konseptor event, stage manager, supporting unit, publisitas, dan media relations (Dewi \& Runyke 2013).

Meskipun demikian, dari penelitian ini terungkap bahwa Munasain belum banyak dikenal dan dikunjungi masyarakat. Demikian juga dengan fungsi dan manfaat Munasain, masih perlu terus ditingkatkan. Oleh karena itu perlu dirancang strategi sosialisasi dan promosi yang lebih progresif. Dengan dukungan 19 orang pranata humas yang terdiri atas jenjang terampil dan ahli untuk kawasan Bogor, Munasain memiliki sumber daya manusia pengelola yang cukup. Pranata humas dapat membantu menyusun rencana dan strategi pelayanan informasi dan kehumasan, penyedianan bahan informasi dan konten kreatif, 
pelaksanaan program kehumasan serta monitoring dan evaluasi (PERMENPANRB No.6 Tahun 2014). Sesuai dengan tujuan LIPI untuk peningkatan budaya ilmiah masyarakat Indonesia, target penerima manfaat Munasain terutama ditujukan bagi siswa, mahasiswa serta peneliti. Untuk itu perlu disusun konten-konten komunikasi serta cara pengemasan yang sesuai dan disukai generasi muda dan akademisi (dosen/peneliti).

Di masa pandemic covid-19 ini, isu tentang pemanfaatan bahan alam berupa herbal sebagai imuno modulator menjadi salah satu informasi hasil penelitian LIPI yang banyak diminati peneliti dan dosen. Melalui kegiatan dialog dengan peneliti di Munasain (science briefing), seminar/ webinar seri budaya dan sejarah alam, serta pelaksanaan kalender kegiatan (calendar of event) bagi siswa dan masyarakat, informasi tentang hasil riset dan koleksi Munasain tersosialisasikan. Peningkatan kualitas display tematik Munasain, dapat dilakukan melalui kerja sama kemitraan model pentahelix, yaitu pemerintah, komunitas, akademisi, perusahaan dan media massa. Beberapa komunitas milenial seperti Bogor Sketchers dan komunitas tari tradisional sudah rutin beraktivitas di Munasain.

Di masa pandemic Covid-19 ini telah terjadi perubahan cara komunikasi. Pranata humas harus beradaptasi dan terampil dalam penggunaan media komunikasi digital. Salah satu program komunikasi yang banyak dilakukan saat ini yaitu: kunjungan virtual, story telling digital serta interaksi secara online lainnya. Selain itu pemanfaatan media sosial menjadi sangat penting. Media sosial sangat digemari generasi muda untuk mendapatkan informasi. Kanal media sosial yang banyak digemari generasi muda saat ini yaitu: Instagram, facebook dan youtube. Dari berbagai referensi juga terbukti bahwa media sosial memiliki peran yang sangat efektif sebagai media sosialisasi dan promosi. Media sosial adalah sebuah media online di mana penggunanya dapat dengan mudah berpartisipasi, berbagi, membuat konten atau tulisan. Melalui media sosial suatu lembaga dapat mengenal pelanggan lebih dekat; mendengar keinginan pelanggan; merespon dengan cepat; melihat persaingan pasar; dan meningkatkan pengunjung website (http://www.jurnal.id). Melalui media sosial, para peminat munasain dapat lebih mudah mencari dan mengetahui informasi tentang program atau acara yang diselengggarakan oleh Munasain.

Kini media sosial berkembang menjadi salah satu alat promosi yang penting. Teknik pemasaran dengan media sosial dianggap menjadi salah satu cara yang paling ampuh untuk mengembangkan usaha karena media sosial bisa menjangkau lebih banyak orang; praktis dan cepat dalam menyebarkan informasi; bisa mengukur dan melihat karakteristik target pasar; membangun brand awareness; dan membangun koneksi dengan klien dan pelanggan (Ocho, 2019). Pada masa pandemi covid-19, acara ngabuburit di Munasain juga diselenggarakan secara on line menggunakan platform zoom.

\section{Kesimpulan}

Museum memiliki peran yang penting dalam komunikasi pembangunan, terutama pembangunan karakter bangsa yang cinta tanah air melalui edukasi dan rekreasi kepada generasi muda. Munasain merupakan salah satu sarana LIPI untuk meningkatkan budaya ilmiah masyarakat, khususnya bagi generasi muda dan akademisi. Hasil penelitian menunjukkan bahwa peminat Munasain terbesar adalah kelompok umur 21-30 tahun yang terdiri atas dosen dan mahasiswa. Sebagian besar responden belum pernah berkunjung ke Munasain dan memperoleh informasi tentang Munasain dari media sosial. Tema Munasain 
yang diminati adalah tentang etnobotani, koleksi sejarah dan budaya, serta sejarah alam Indonesia. Bagi responden, Munasain dinilai istimewa dibanding museum lain karena merupakan sumber pengetahuan yang lengkap, display-nya menarik, serta memiliki koleksi etnobotani sebagai unggulan. Keberadaan Munasain perlu disosialisasikan dan dipromosikan serta ditingkatkan kualitas display koleksinya. Strategi komunikasi melalui media sosial untuk menampilkan konten yang menarik dan kreatif perlu dikembangkan untuk pengelolaan ke depan.

\section{Ucapan Terima Kasih}

Terima kasih disampaikan kepada narasumber acara Ngabuburit di Munasin tanggal $18 \mathrm{Mei}$ 2020 yaitu Dr. Atit Kanti (Kepala Puslit Biologi LIPI), Prof. Dr. Andria Agusta (Puslit Kimia LIPI) dan Dr. Herry Yogaswara (Kepala Puslit Kependudukan LIPI). Terima kasih juga disampaian kepada kru/panitia penyelenggara yaitu Dr. Fathi Royyani, Sri Handayani, Doni Darussalam, Medi Sutiyatno, Marwan Setiawan, Uus Faizal Firdaussy, Dicky Kurniawan, dan Fahmi.

\section{Daftar Pustaka}

Abdillah, A.B.Y., Hamid, D., \& Topowijono. (2016). Dampak Pengembangan Pariwisata Teradap Kehidupan Masyarakat Lokal di Kawasan Wisata (Studi Pada Masyarakat Sekitar Wisata Wendit, Kabupaten Malang). Jurnal Administrasi Bisnis (JAB), 30 (1), 74-78.

Akbar, Ali. (2010). Museum di Indonesia, Kendala dan Harapan. Jakarta: Papas Sinar Sinanti.

Asmara, D. (2019). Peran Museum Dalam Pembelajaran Sejarah. Jurnal Pendidikan Sejarah dan Riset Sosial Humaniora. 2(1), 2598-4934.

BPS Kota Bogor. (2018). Kota Bogor Dalam Angka 2018. Bogor: Badan Pusat Statistik. BPS Kota Bogor. (2020). Kota Bogor Dalam Angka 2020. Bogor: Badan Pusat Statistik.

Brosur "Museum Etnobotani Indonesia" (Lembaga Ilmu Pengetahuan Indonesia)

Cutlip SM, Center AH \& Broom GM. Effective Public Relations, Ed. 9. Jakarta : Kencana; 2009.

Dewi, M. \& Runyke, M. (2013). Peran Public Relations dalam Manajemen Event (Studi Terhadap Peran Public Relations Galeria Mall dan Plaza Ambarrukmo dalam Pengelolaan Event Tahun 2013). Jurnal komunikasi, 8(1), 79-90.

Falk, J. (2012). Visitor Studies. Encyclopedia of Science Education. Springer Science+Business Media Dordrecht. DOI 10.1007/978-94-007-6165-0_341-1

Gaffar, V. (2011). Pengaruh Strategi Positioning Museum Terhadap Kunjungan Wisata Edukasi Di Kota Bandung (Survey Segmen Pasar Generasi Y). Tourism and Hospitality Essentials (THE) Journal, 1(1), 15-32.

Gasperzs V. (1991). Metode perancangan percobaan. Bandung: Armico.

Handoko, G.S., Djono, D., \& Yunianto, T. (2018). Pemanfaatan Museum Pura Mangkunegaran Sebagai Media Pembelajaran IPS. Jurnal Candi, 17(1), 129-142.

http://lipi.go.id/lipimedia/museum-nasional-sejarah-alam-indonesia-tampil-segar/20609 http://munasain.lipi.go.id/

http://www.jurnas.com/artikel/16942/Belum-Tau-arti-Ngabuburit-Ini-Penjelasannya/ http://www.museumindonesia.com/museum/15/1/Museum Etnobotani Indonesia Bogor https://journal.sociolla.com/lifestyle/media-sosial-adalah-sarana-promosi/ 
https://kbbi.web.id/museum

https://www.jurnal.id/id/blog/2017-5-alasan-kenapa-bisnis-membutuhkan-media-sosial/ https://www.jurnal.id/id/blog/2017-5-alasan-kenapa-bisnis-membutuhkan-media-sosial/ ICOM. (2017). ICOM Code of Ethics for Museums. France: International Council of Museums (ICOM)

Karyono. (2010). Pemanfaatan Museum Sebagai Media Pembelajaran untuk Meningkatkan Pemahaman Siswa Terhadap Materi Prasejarah Bagi Guruguru SMA Kota Semarang. Jurnal Abdimas, 14(1), 1-7.

Kirom, N.R., Sudarmiatin, \& Putra I.WJ.A. (2016). Faktor-Faktor Penentu Daya Tarik Wisata Budaya Dan Pengaruhnya Terhadap Kepuasan Wisatawan. Jurnal Pendidikan: Teori, Penelitian, dan Pengembangan, 1(3), 536-546.

Kotler, P. \& Keller, K.L. (2007). Manajemen Pemasaran Jilid 1, Edisi 12. Jakarta: PT. Indeks.

Mardikanto, T. (2010). Komunikasi Pembangunan, Acuan Bagi Akademisi, Praktisi dan Peminat Komunikasi Pembangunan. Surakarta: UNS Press

Nazir, M. (1988). Metode Penelitian. Jakarta: Ghalia Indonesia.

Nova, F. (2009). Crisis Public Relations: Bagaimana PR Menangani Krisis Perusahaan. Jakarta: PT Grasindo.

Nuraeni, B.S. (2014). Analisis Faktor-Faktor yang Mempengaruhi Minat Kunjung Ulang Wisatawan Museum Ranggawarsita Semarang. Jurnal Bisnis Strategi, 23(1), 1-20.

Nurnisya, F.Y. \& Nurjanah, A. (2016). Peran Humas Pemerintahan Kota Yogyakarta dalam Sosialisasi Tagline "Jogja Istimewa". Channel, 4(2), 135-152.

Ochi, E. (2019). Ini Alasan Mengapa Media Sosial adalah Sarana yang Tepat untuk Menunjang Pemasaran Bisnis. Diposting 29 Jul 2019. https://journal.sociolla.com/ lifestyle/media-sosial-adalah-sarana-promosi/

Pamungkas, B.A. \& Zuhroh, S. (2016). Pengaruh Promosi Di Media Sosial Dan Word Of Mouth Terhadap Keputusan Pembelian. Komunikasi, 10(02),145-160.

Peraturan Menteri Pendayagunaan Aparatur Negara dan Reformasi Birokrasi Republik Indonesia Nomor 6 Tahun 2014 Tentang jabatan Fungsional Pranata Hubungan Masyarakat dan Angka Kreditnya.

Purbohastuti, A.W. (2017). Efektivitas Media Sosial Sebagai Media Promosi. Tirtayasa Ekonomika, 12(2), 212-231.

Ruslan, R. (2012). Manajemen Public Relations Media Komunikasi. Jakarta: PT Rajagrafindo Persada.

Sarwono, J. (2006). Metode Penelitian Kuantitatif dan Kualitatif. Yogykarta: Graha Ilmu.

Satori, D, \& Komariah, A. (2009). Metodologi Penelitian Kualitatif. Bandung: Alfabeta.

Schacter, D.L., Gilbert, D.T., \& Wegner, D.M. (2011). Psychology (2nd Edition). New York: Worth.

Sugiyono. (1999). Statistik Non Parametris untuk Penelitian. Bandung: CV Alfabeta.

Suryani, I. (2014). Pemanfaatan Media Sosial sebagai Media Pemasaran Produk dan Potensi Indonesia dalam Upaya Mendukung ASEAN Community 2015. Jurnal komunikasi, $8(2), 123-138$.

Suryasih, I.A. (2010). Memagnetik Pengunjung Museum dalam Menyongsong Visit Museum Years 2010. Analisis Pariwisata, 10(1), $91-96$.

Tjiptono, F. (2001). Strategi Pemasaran. Edisi Pertama. Yogyakarta: Andi Ofset.

Yusuf, M.A., Ibrahim, N., \& Kurniawati. (2018). Pemanfaatan Museum Sebagai Sumber Belajar Dalam Pembelajaran Sejarah. Jurnal Visipena, 9(2), 215-235. 
Wahyuningsih, I. (2020). Meninjau Kembali Tujuan Pendirian dan Fungsi Museum-museum di Kompleks Taman Wisata Candi Borobudur. Jurnal Konservasi Cagar Budaya Borobudur, 10(2): 43-55. 


\section{Lampiran}

Tabel 1. Asal Peserta Ngabuburit di Munasain, 2020

\begin{tabular}{llrrlr}
\hline No & Asal & Jumlah & No & Asal & Jumlah \\
\hline 1 & Jawa Barat & 74 & 16. & Kalimantan Barat & 3 \\
\hline 2 & DKI Jakarta & 73 & 17. & Nusa Tenggara Barat & 3 \\
\hline 3 & Jawa Timur & 39 & 18. & Nusa Tenggara Timur & 3 \\
\hline 4 & Sulawesi Selatan & 27 & 19. & Bali & 2 \\
\hline 5 & Jawa Tengah & 22 & 20. & Kalimantan Tengah & 2 \\
\hline 6 & D.I. Yogyakarta & 13 & 21. & Kepulauan Riau & 2 \\
\hline 7 & Sumatera Selatan & 9 & 22. & Sumatera Utara & 2 \\
\hline 8 & Banten & 7 & 23. & Bangka Belitung & 1 \\
\hline 9 & Sulawesi Tenggara & 7 & 24. & Maluku & 1 \\
\hline 10 & Lampung & 6 & 25. & Papua & 1 \\
\hline 11 & Jambi & 5 & 26. & Papua Barat & 1 \\
\hline 12 & Maluku Utara & 5 & 27. & Riau & 1 \\
\hline 13 & Kalimantan Timur & 4 & 28. & Sumatera Barat & 1 \\
\hline 14 & Nangroe Aceh Darusalam & 4 & 29. & Cambridge & 1 \\
\hline 15 & Gorontalo & 3 & 30. & Malaysia & 323 \\
\hline
\end{tabular}

Tabel 2. Keistimewaan Munasin Menurut Responden Dibandingkan Museum Lain, 2020

\begin{tabular}{llrr}
\hline No. & \multicolumn{1}{c}{ Keistimewaan Munasain Menurut Responden } & $\begin{array}{c}\text { Jumlah } \\
\text { Jawaban } \\
\text { responden }\end{array}$ & Persentse \\
\hline 1. & $\begin{array}{l}\text { Sumber pengetahuan yang lengkap tentang etnobotanidan sejarah } \\
\text { alam. }\end{array}$ & 29 & $31,2 \%$ \\
\hline 2. & Display-nya menarik & 27 & $29,0 \%$ \\
\hline 3. & Koleksi etnobotani satu-satunyadi Indonesia & 17 & $18,3 \%$ \\
\hline 4. & Koleksi kerajinan dariberbagai daerah & 7 & $8,6 \%$ \\
\hline 5. & Suasana di dalam museum kental dengan nuansailmiah (saintifik) & $7,5 \%$ \\
\hline 6. & Memamerkan ragam kearifan lokal Nusantara & 5 & $5,4 \%$ \\
\hline & Jumlah & 93 & $100,0 \%$ \\
\hline
\end{tabular}


Tabel 3. Kontingensi Antara Profesi Responden Dengan Tema yang Diminati, 2020

\begin{tabular}{llcccc}
\hline \multirow{2}{*}{ No. } & Profesi & \multicolumn{3}{c}{ Tema yang diminati } & Jumlah \\
\cline { 3 - 6 } & & Sejarah alam dan Budaya & Lainnya & Etnobotani & \\
\hline 1. & Umum & 5 & 0 & 2 & 7 \\
\hline 2. & Dosen & 32 & 2 & 24 & 58 \\
\hline 3. & Guru & 9 & 1 & 19 & 52 \\
\hline 4. & Mahasiswa & 32 & 0 & 2 & 9 \\
\hline 5. & Pelajar & 7 & 0 & 17 & 29 \\
\hline 6. & Peneliti & 12 & 0 & 1 & 3 \\
\hline 7. & Penyuluh & 2 & 1 & 8 & 31 \\
\hline 8. & PNS & 22 & 4 & 79 & 204 \\
\hline & & 121 & & & \\
\hline
\end{tabular}

Tabel 4. Tabel kontingensi antara profesi responden dengan aspirasi terhadap Munasain, 2020.

\begin{tabular}{llrrrrr}
\hline No. & Profesi & $\begin{array}{c}\text { Display yang } \\
\text { menarik }\end{array}$ & $\begin{array}{c}\text { Menambah } \\
\text { koleksi }\end{array}$ & $\begin{array}{c}\text { Peningkatan } \\
\text { Manfaat } \\
\text { Munasain }\end{array}$ & $\begin{array}{c}\text { Sosialisasi/ } \\
\text { Promosi ke } \\
\text { publik }\end{array}$ & $\begin{array}{c}\text { Jumlah } \\
\text { Responden }\end{array}$ \\
\hline 1. & Umum & 1 & 2 & 1 & 3 & 7 \\
\hline 2. & Dosen & 6 & 5 & 15 & 21 & 47 \\
\hline 3. & Guru & 3 & 0 & 5 & 4 & 12 \\
\hline 4. & Mahasiswa & 3 & 3 & 14 & 22 & 42 \\
\hline 5. & Pelajar & 0 & 2 & 1 & 4 & 7 \\
\hline 6. & Peneliti & 4 & 2 & 10 & 6 & 22 \\
\hline 7. & Penyuluh & 0 & 0 & 1 & 0 & 1 \\
\hline 8. & PNS & 9 & 0 & 4 & 11 & 24 \\
\hline & & 26 & 14 & 51 & 71 & 162 \\
\hline
\end{tabular}

